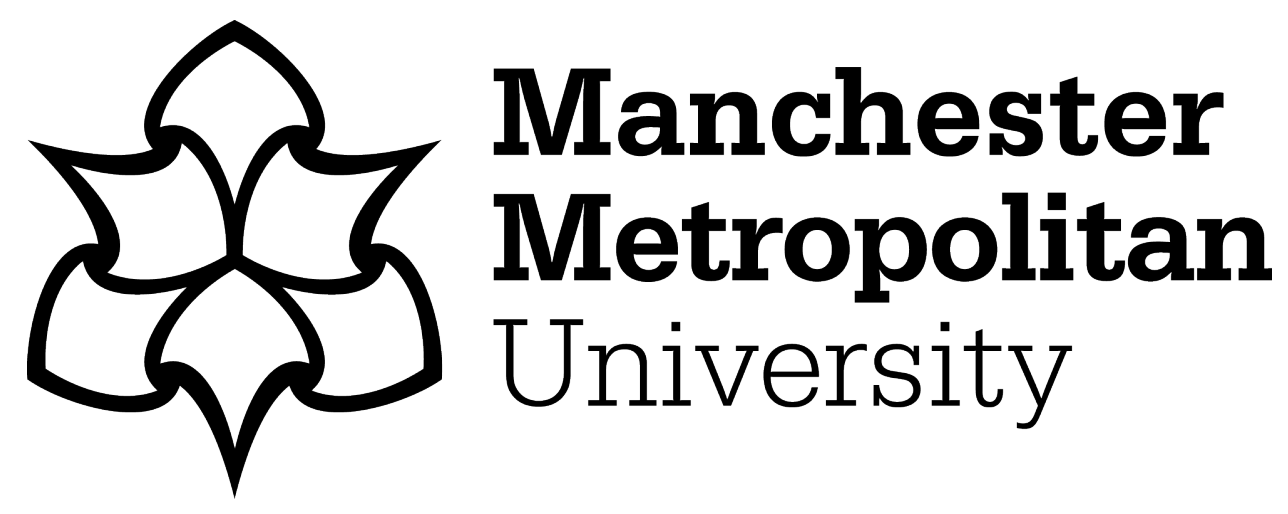

Fenemore, Mark (2015) Youth Opposition in the GDR, 1945-1965. Totalitarianism and Democracy, 12 (2). pp. 249-268. ISSN 1612-9008

Downloaded from: https://e-space.mmu.ac.uk/621564/

Version: Accepted Version

Publisher: Vandenhoeck \& Ruprecht GmbH \& Co.

DOI: https://doi.org/10.13109/tode.2015.12.2.249

Please cite the published version 


\title{
Youth Opposition in the GDR, 1945-1965
}

\author{
Mark Fenemore (Manchester Metropolitan University) \\ published in Totalitarismus und Demokratie 13 (2015), 207-220. ISSN: 1612-9008.
}

The SED leadership had a whole arsenal of weapons of coercion at its disposal, which were regularly used on those young people who were seen to be straying from the path set out for them by the Party. In schools and on the streets, instances of indiscipline and unruliness were routinely interpreted by the authorities as "attacks on the state". The regime's need to generate rituals and proofs of loyalty led to repression against individuals when they failed to live up to its expectations. It claimed to have a monopoly on youth and the power to mould young people as future citizens. Youth was prized as a particularly creative and malleable part of the population. Being put on a pedestal like this was flattering but also dangerous for teenagers.

In addition to this background level of repression of nonconformity, there were periodic campaigns of persecution directed at particular groups. In the early 1950s, the major focus was on young Christians, who belonged to the Junge Gemeinde, particularly in the Oberschulen. ${ }^{1}$ With the emergence of recognisable youth subcultures (first Bebop fans then rockers) in the early-to-mid-1950s, the Party was provided with new and highly visible targets for public condemnation and official harassment. This article explores the influence of Stalinism on the Party and assesses whether the methods used by the SED, in its bid to coerce

\footnotetext{
${ }^{1}$ Dorothee Wierling, "Die Jugend als innerer Feind. Konflikte in der Erziehungsdiktatur der sechziger Jahre". In: Hartmut Kaelbe/Jürgen Kocka/Hartmut Zwahr (Eds), Sozialgeschichte der DDR, Stuttgart 1994, pp. 404425, here 407.
} 
young people into conformity, really were "just like the Nazis". It also raises the issue of "moral panics", which were neither wholly Stalinist nor Nazi in origin, and which constituted the prevalent mode of misrepresenting and attacking youth subcultures in both East and West. While recognizing that the GDR was a dictatorship, which sought to exert a total claim on the population, it is also important to assess the areas where supposedly "common sense", authoritarian responses to youth deviance also existed in liberal democracies. ${ }^{2}$ The GDR did not have a monopoly on conservatives who feared youthful exuberance and nonconformity.

\section{STALINIST OVERTONES}

Particularly in the early years of the regime's existence, while Stalin was still in power in the Soviet Union and the Soviet occupying forces continued to play a crucial role in shaping and influencing the development of socialism in the GDR, regime attempts to punish and control youth nonconformity could be described as "Stalinist" in their language and methodology. ${ }^{3}$ Recurrent themes in the Stalinist-style rhetoric involved "infiltration" and "sabotage" by spies and traitors, together with the work of the counter-revolutionary fifth column. The cold war was real enough, but fear of western contamination developed into a form of paranoia. According to this mind-set, attacks on the GDR came from a bewilderingly wide range of sources, but were all connected in a concerted, covert onslaught, orchestrated by western agencies. At this time, the GDR heavily borrowed political rituals and ceremonies from the

\footnotetext{
${ }^{2}$ In the mid-1950s, British Home Secretary R. A. Butler announced the hasty construction of Detention Centres for juveniles: „Everything should be done at the double... there should be a maximum of hard work and a minimum of amusement.“ Geoffrey Pearson, Hooligan: A History of Respectable Fears, New York 1984, p. 13.

${ }^{3}$ Ian Kershaw/Moshe Lewin (Eds.), Stalinism and Nazism: dictatorships in comparison, Cambridge 1997; Sheila Fitzpatrick, Stalinism: a reader, London/New York, 1999.
} 
Soviet „,big brothers”. ${ }^{4}$ The October Revolution and Soviet victory against National Socialism were seen as major sources of legitimacy. Adopting Soviet rituals and rhetoric was a way of establishing one's loyalty and disguising any continuities with the Third Reich.

To a much greater extent than for subsequent Soviet leaders, attempts were made to generate a cult of personality for Stalin among East German youth. In the run up to Christmas 1949, Communists in the education ministry and the FDJ tried to have the traditional Christian emphasis on the 25 December, as a celebration of the nativity of Christ, replaced with a commemoration, instead, of Stalin's birth which fell on the 21 December. ${ }^{5}$ Not surprisingly, this attempt to substitute a popular festival traditionally accompanied with eating, drinking and making merry with a dour celebration of the anniversary of a man responsible for the deaths and disappearance of millions of people (including hundreds of thousands of their fellow countrymen in the postwar period) was more than many young people could stomach. Nevertheless, the authorities were determined to punish any young person who failed to show the requisite degree of solemnity and respect during these birthday celebrations. A group of sixth formers in Dresden used the occasion to make an ironic protest against the regime. They celebrated Stalin's birth with not one but three portraits and hung up the ironic slogan „Stalin, der Genius der Menschheit!”6

\footnotetext{
${ }^{4}$ Jürgen Danyel, "Politische Rituale als Sowjetimporte". In: Konrad Jarausch/Hannes Siegrist (Eds.), Amerikanisierung und Sowjetisierung in Deutschland, 1945-1970, Frankfurt/New York 1997, pp. 67-86, here 70.

${ }^{5}$ Joachim Petzold, Zum Verhältnis zwischen FDJ und Junger Gemeinde bis 1953. In: Helga Gotschlich (Ed.), “Links und links und Schritt gehalten...”. Die FDJ: Konzepte - Abläufe - Grenzen, Berlin 1994, pp. 127-140, p. 134.

${ }^{6}$ Ibid., p.135.
} 
Anything short of complete enthusiasm for Soviet-style Communism and Stalin posed a threat of disloyalty to the Party. Fresh from a trip to Moscow, in December 1949, after being demoted, Horst Sindermann outlined the groups that he held responsible for slowing down the development and take up of socialism in the eastern Zone. Leipzig, once proclaimed as the birthplace of Social Democracy, was now denigrated as „die Hochburg der Schumacherideologie”, a city tainted with its long tradition of „Revisionismus”. ${ }^{7}$ Just three years after the forced merger of the SPD with the KPD and only two months after the founding of the GDR, Sindermann warned of the dangerous existence of „kleinbürgerlichen Schumacherischer Tendenz” in the Leipzig teaching profession ,,auch unter den Lehrern, die Genossen unserer Partei sind”. The teacher's union, in particular, represented „das Zentrum dieser Rückständigkeit“ in Leipzig. For Sindermann, there was only one option: „Wir müssen mutig und kühn die feindlichen Agenturen und ihre Nester aufstöbern, sie zerschlagen und sie vor der Mitgliedschaft und der gesamten Bevölkerung als Zentralen der feindlichen englisch-amerikanischen Monopolkapitals entlarven. ${ }^{\text {(68 }}$

In the immediate postwar period, the Communists had sought to establish their credentials as open and accepting democrats. The early inclusiveness was now jettisoned in favour of sectarianism, uniformity and repression. Attacks on Liberals and Social Democrats within the teaching profession coincided with the arrest and imprisonment of pupils in the Oberschulen for minor acts of disobedience and nonconformity. Together, teachers and "bourgeois, middle class" pupils were supposedly colluding in hampering the development of socialism and the

\footnotetext{
${ }^{7}$ West German Social Democratic leader, Kurt Schumacher, had strongly opposed the merger of the SPD with the KPD in the Soviet zone.

${ }^{8}$ Referat des neuen Kreisvorsitzenden der SED, Horst Sindermann auf der Stadtdelegierten-Konferenz Leipzig am 1. und 2 Dezember 1949 (Sächsisches Staatsarchiv Leipzig, IV-5/01/003).
} 
correct class consciousness among young people. In a general atmosphere of fear and confusion, purges and show trials were implemented by the Ministries of State Security and Justice, without key members of the administration, like Otto Grotewohl, being informed. At the beginning of October 1951, Prime Minister Grotewohl was presented with a copy of a West Berlin newspaper. From it, he learned that on the 3 October 1951 a political trial was due to take place against 19 Oberschüler from Werdau before the district court in Zwickau. The article reckoned that the pupils would be given long sentences. It further predicted that only members of Communist organizations would be allowed to observe the proceedings. ${ }^{9}$ Grotewohl asked the Justice Ministry to delay or abandon the trial, but by the time a representative had been sent to Zwickau, sentences of between two and fifteen years had already been passed down. In fact, just after midnight on the night of the 3-4 October, the nineteen Oberschüler were sentenced to a total of 130 years in prison. Their crime had been to distribute leaflets criticising the undemocratic nature of the so-called „People's Elections”. They had further denounced the decision of the „unelected Pankow regime” to condemn an Oberschüler to death for distributing other anti-regime leaflets. ${ }^{10}$

Interestingly, the way in which the MfS had carried out this and other trials against Oberschüler in Saxony had produced „strong opposition” not just among the general population but even within „our government and the Politbüro”. The „opposition” on the part of regime leaders stemmed not so much from the fact that the trials and the sentences handed

\footnotetext{
${ }^{9}$ Vertraulich! Nicht in den Geschäftsgang geben! Bericht: Prozeß gegen 19 Werdauer Oberschüler am 3.10.1951 (BArch. SAPMO DY30/IV2/905/42).

${ }^{10}$ For a full account of the trial by one of those accused, see Achim Beyer, Der Prozeß gegen die "Werdauer Oberschüler" 1951. Jugendwiderstand in der SBZ/DDR. In: Deutschland Archiv, 31:1 (1998), pp. 86-97. The regime saw the death sentence as legitimate because the pupil (Hermann Flade) had resisted his arrest with a pocket knife. However, under international pressure, they later commuted it.
} 
down were patently unjust and excessive, but because their lack of information about the trials made it impossible for Party functionaries to ,prepare and carry out the necessary political steering". News of the trial had spread, via western press reports and RIAS broadcasts, to Werdau, described as ,,a centre of sectarianism”, and Crimmitschau, dubbed ,a stronghold of Social Democracy". ${ }^{11}$

The „Stalinist” character of these early assaults against groups of young people defined and labelled as nonconformist by the authorities, was particularly apparent in the offensive against the Junge Gemeinde carried out in the Spring of 1953. Combining high-profile denunciation in the media with a carefully orchestrated series of show trials and public purges in the Oberschulen, the campaign was designed to strike terror into the hearts of young Christians and to show them that the regime meant business. ${ }^{12}$ As Erich Honecker put it in instructions to his FDJ troops: „Deshalb sind in Verbindung mit der breitesten Aufklärungsarbeit unter der Jugend und Bevölkerung alle Massnahmen zu treffen... in Bezug auf die Reinigung der Oberschulen und Universitäten... Es besteht kein Zweifel, dass bei einer entsprechenden Aufklärungsarbeit in kurzer Zeit das von uns gesteckte Ziel der Liquidierung der Jungen Gemeinde erreicht werden kann.“"13 The Communist leadership suspected that middle-class and Christian Oberschüler were behind the poor performance of working-class youth in education and the lacklustre activities of the FDJ. In rural communities, in particular, the FDJ was failing to compete effectively with the much more

\footnotetext{
${ }^{11}$ Prozeß gegen 19 Werdauer.

${ }^{12}$ Politbüro Protokoll Nr. 5/53 v. 27. Jan. 1953 (BArch SAPMO, JIV2/2-259).

${ }^{13}$ Fernschreiben an der 1. Sekretäre der Bezirksleitungen der Freien Deutschen Jugend, April 1953 (BArch SAPMO DY24/11.895, pp. 40-41).
} 
popular Junge Gemeinde. A report from Flöha outlined the dangerous threat posed by this organization of young Christians:

Die Mitglieder der FDJ gehen nicht in die Heimabende, sondern zu dieser christlichen Jugend. Es gibt dort Mitgliedskarten. Die Abende finden in Privatwohnungen statt. Sie lassen sich nie in Diskussionen (politische) ein. Sind bereit, mit der FDJ zusammenzuarbeiten, lehnen aber jeden Zusammenschluss ab. Man spricht über Goethe, Heine und singt kirchliche Lieder, sobald aber ein Fremder mitkommt, bleibt man heilig. ${ }^{14}$

Other local FDJ commanders reported the opposite. Christians used innocent-seeming leisure opportunities as a means of talking young atheists into abandoning their secular beliefs and becoming Christians.

In fact, many Christians were members of both organizations and those people who were keenly involved in Junge Gemeinde activities were often also functionaries in the FDJ. Unfortunately, this only hardened the leadership's suspicions by suggesting that young Christians were deliberately infiltrating the youth organization in order to subvert and undermine it from within. Christian function-holders in the FDJ were accused of throwing a spanner in the works by deliberately making FDJ activities dull and uninteresting. The fact that convinced atheists were just as likely to hold tedious and unimaginative FDJ meetings was not enough to prevent the authorities embarking on a full-scale purge in which members of the youth organization were required to surrender their membership cards. The attack on Christian infiltration of the youth organization was pushed forward as if it was a real purge.

\footnotetext{
${ }^{14}$ Vertraulich! Abschrift der Berichte aus den Kreisen, No date, ca. 1947 (BArch SAPMO DY24/3817).
} 
Christians who had insinuated their way into the youth organization were „exposed” and incriminated. ${ }^{15}$ Local functionaries transformed routine and humdrum youth club activities into the work of „spies“, ,agents” and „traitors”.

The campaign against the Junge Gemeinde also represented the SED's first use of mass media in a campaign against a section of youth. In the West, tabloids routinely trade in lies and innuendo. They stretch the truth and make the evidence fit their particular agenda. Opponents are easily smeared and maligned. In April 1953, young Christians had organized a retreat in Sehlis, a small village on the outskirts of Leipzig. In its report on this supposed „Lager“, the Leipziger Volkszeitung used all its powers of misrepresentation and insinuation. ${ }^{16}$ The article gives an example of the type of inflammatory and muckraking rhetoric the Party used against the Junge Gemeinde. The headline ran „'Junge Gemeinde’ - Tarnorganisation im USA-Auftrag“. The newspaper outlined „Wie junge Menschen unter Mißbrauch religiöser Gefühle zu Verbrechern aufgewiegelt werden." Other examples of the Junge Gemeinde's misdeeds were summarized under subheadings which sounded more like the titles of trash novels: „Agenten und Provokateure im Priesterrock“, „The SS Death's head was the symbol“ and „Fascist songbooks for ,spiritual edification,”.

The Junge Gemeinde was said to be controlled by the CIA and was an extension of ,the fascist terror organization, the BDJ““. ${ }^{17}$ Needless to say, the BDJ (a West German neo-Nazi youth organization using the name Bündische Jugend) had no connections whatever with the

\footnotetext{
${ }^{15}$ Eye-witness accounts of how the purges were experienced are given in Patrik von zur Mühlen, Der “Eisenberger Kreis" Jugendwiderstand und Verfolgung in der DDR, 1953-1958, Bonn 1995, pp. 27-28.

16 “Junge Gemeinde" - Tarnorganisation im USA-Auftrag. In: Leipziger Volkszeitung 19.4.1953.

${ }^{17}$ Ibid. Cf. Faschistische Umtriebe des "BDJ" unter dem Deckmantel der illegalen "Jungen Gemeinde”. In: Neues Deutschland 28.4.1953.
} 
Junge Gemeinde. The important thing was to build up a composite web of attributions so that young people could be judged guilty by association. The „evidence“ for the accusations of pro-fascism came in the form of a photograph purportedly showing a death's head symbol. The paper accused the Christians of secretly painting „SS death's heads“ and thereby revealing a murderous intent. Most of the information contained in the article was pure fantasy. This sinister and shadowy young Christian organization incited its members to commit hostile acts against the state and tried to embark them on careers in crime. Their ostensible religious activity was merely a cloak for „banditry“. In reality, the paper suggested, they were part of the network of agents and subversives under American secret service control. All this „confirmed“ that the Junge Gemeinde was no religious community, but an illegal terror organization.

The reporters supposedly found a dummy hanging from a tree with a red tie around its neck. This was interpreted as a symbolic hanging and stood in stark contrast to the professed religious activity. Such an outrageous provocation was linked the Klu Klux Klan, and the brutal terror practised by ,Ami-soldiers in Korea“. A single, symbolic tie was enough to condemn the young Christians as being CIA agents. Their place of retreat was now a „nesting place“ for the GDR's sworn enemies. These young people were merely disguised as Christians; behind their outward profession of faith, they practised hatred for progressives rather than brotherly love. The journalists happily embraced their role as smearers and defamers. Their campaign acted as the starting pistol for a wave of condemnation and attacks at the grass roots; the Junge Gemeinde could now be unmasked. CDU member Manfred Klein subsequently suggested that the uniforms and ideological training of the FDJ had proved „psychologically effective“ in creating and heightening divisions between „us“ and 
„them“. ${ }^{18}$ Some of the young people, who had been young children during the Third Reich, embraced the new opportunities for persecuting a visible minority. The regime encouraged them to act out as bullies; it allowed opportunities for ventilating grudges and settling scores. After the first article against the Junge Gemeinde was published in the January edition of Junge Welt, one young FDJ member (who had supposedly previously also once been a member of the Junge Gemeinde) wrote to in to say that „Diese Menschen können unserer Republik nur schaden. Es sind feindliche Elemente, die sich hinter einer Maske verbergen und entlarvt und vernichtet werden müssen.“"19

The violence of the language is interesting on a psychological level. As Adorno argued in 1959, many Germans were ,indifferent to democracy, where they don't secretly hate it““. ${ }^{20}$ Elizabeth Ten Dyke argues that „Many characteristics of the authoritarian personality Adorno described seem to apply to East Germans. These include a weak ego, rigidity, conformism, conventionality, and the penchant to subordinate one's self to larger groups. ${ }^{\text {“21 }}$ While sweeping claims about „deformed personalities“ are problematic, the evidence suggests that the lessons from the Nazi past had not been learnt by many conformist East Germans in early 1953. The linguist Victor Klemperer recorded how Nazism had polluted language and thinking in Germany and persisted after the foundation of the GDR. ${ }^{22}$ In June 1953, East

\footnotetext{
${ }^{18}$ Manfred Klein, Jugend zwischen den Diktaturen: 1945-1956, Mainz 1968, p. 79.

${ }^{19}$ VEB Kombinat “Otto Grotewohl”, Jan 1953 (BArch SAPMO DY24/11.895).

${ }^{20}$ Theodor W. Adorno, The Authoritarian Personality, New York 1950; Idem., What does Coming to Terms with the Past Mean? In: Timothy Bahti/Geoffrey Hartman (Eds.), Bitburg in Moral and Political Perspective, Bloomington 1986, pp. 114-129, here 125. The essay was originally published in 1959.

${ }^{21}$ Elizabeth Ten Dyke, Dresden: Paradoxes of Memory in History, New York/London 2001, p. 48.

${ }^{22}$ Victor Klemperer, The Language of the Third Reich, translated by Martin Brady, London/New York 2000, p. 2.
} 
Germans rose up en masse in favour of democracy. The Communist authorities insisted that there were National Socialist elements to the anti-Communist fury, but they were forced to backtrack from their repressive course. Even after the campaign against the Junge Gemeinde was called off (under pressure from the Soviets following Stalin's death), there were reports of residual hostility to the Christians: ,aus dem Bezirk Leipzig wir die Tendenz vertreten, 'na lass die 'Junge Gemeinde' nur kommen, nachher machen wir eine Politik, da werden sie alle wieder hinausekeln.” One young ,youth friend“ was particularly upset by the sudden U-turn: „Ich habe mitgestimmt, dass die Mitglieder der 'Jungen Gemeinde' von der Oberschule verwiesen werden und jetzt soll ich mit diesen auf einer Schulbank sitzen, das mache ich nicht mit. “23

\section{NAZI OVERTONES}

As sociologist Stanley Cohen suggested in his important work on „folk devils and moral panics“ in Britain, „the process of spurious attribution is not, of course, random. The audience has existing stereotypes of other folk devils to draw upon and, as with racial stereotyping, there is a readily available composite image which the new picture can be grafted on to. ${ }^{\text {} 24}$ Unfortunately, for the SED, the bank of existing popular stereotypes had already been exploited and plundered by the Nazis. As a result, in trying to whip up „moral panics“ about young people, the Communists had little choice but to re-use labels and images already shopsoiled and over-utilised by their ideological enemies. Consequently, certain aspects of the campaign of vilification and public humiliation against the Junge Gemeinde bore more

\footnotetext{
${ }^{23}$ Information Nr. 4 über die Stimmung und Argumentation zum Kommunique des Politbüros des Zentralkomitees der SED, 15.6.1953 (BArch SAPMO, DY24/2301).

${ }^{24}$ Stanley Cohen, Folk Devils and Moral Panics. The creation of the Mods and the Rockers, London 1972, p. 56.
} 
resemblance to Nazi attacks on „community aliens“ than Soviet-style show trials. In addition to being accused of being fascist, racist and criminal, members of the Junge Gemeinde were also charged with being dirty, unhygienic and potentially sexually deviant. The aim was not just to marginalize and persecute young Christians, but to shame them by tarnishing their respectability.

Problematic for the SED leadership was the fact that although seeming completely normal and second-nature to them, the Stalinist use of purges was deeply upsetting to a population which had just been through twelve years of National Socialist dictatorship. Although the campaign against the Junge Gemeinde was clearly Stalinist in conception, in its concrete implementation it reminded many people of the excesses of National Socialism. Thus parents of pupils purged from the Oberschule in Pößneck complained to Wilhelm Pieck of the „Gestapo methods“ employed by the local FDJ secretary - in keeping a little black book with the names of young people he suspected of being Christian. ${ }^{25}$ The language of ,national community" was also apparent in the aftermath of the June 17th uprising, when young people involved in subcultures were singled out for punishment and blame. Juxtaposing popular folk traditions familiar to older generations (,our good old folk songs“) with the new and alien fashions among youth, the authorities sought to scapegoat gang members for the uprising and drive a wedge between them and the rest of the working-class community. The authorities printed mugshots of young people who had been involved and asked the population to judge for themselves. ${ }^{26}$

\footnotetext{
${ }^{25}$ Ministerium für Volksbildung: Lage in Gera, June 1953 (BArch Berlin, DR2/4899, p. 63).

${ }^{26}$ Urteilt selbst! In: Leipziger Volkszeitung, 24.6.1953, p. 3.
} 
Far from shying away from the label of being ,just like the Nazis“, at times the German Communists went out of their way to pursue policies and methods which were very similar to those the Nazis had used in their own attacks on nonconformity and deviance. ${ }^{27}$ The Nazis had been plagued by a range of youth subcultural cliques like the Edelweiss Pirates and the Leipziger Meuten. ${ }^{28}$ Although there is little evidence of direct crossovers or a continuous existence during the late 1940s, the „packs“" were back on the streets of central Leipzig in the early 1950s. These gangs were an odd hybrid of overlapping cultural elements. Many of the youngsters (mostly young men), who clustered on the street corners and in front of the cinemas, were working class. Like their predecessors, they were macho and territorial, but they were now also heavily influenced in their choice of music and fashion by the example of Halbstarken culture and Rock „,n“ roll spreading from the West. ${ }^{29}$ It was relatively easy in the 1950s (compared to the situation after the wall was built) for young people to travel to West Berlin and get hold of jeans and leather jackets. They could also visit the cinemas and buy comic books, records and trash literature. Stations like RIAS (Radio in the American Sector) and AFN (American Forces Network) helped to spread the raucous and supposedly inflaming

\footnotetext{
${ }^{27}$ Detlev J. K. Peukert, Inside Nazi Germany: conformity, opposition and racism in everyday life, London 1987, p. 168. One key way the Nazis differed was in imposing forced sterilizations. Oded Heilbronner, From a Culture for Youth to a Culture of Youth: Recent Trends in the Historiography of Western Youth Cultures. In: Contemporary European History, 17:4 (Nov. 2008), pp. 575-591, p. 583.

${ }^{28}$ Peukert, Inside Nazi Germany, p. 165f.; Alexander Lange, Meuten, Broadway-Cliquen, Junge Garde: Leipziger Jugendgruppen im Dritten Reich, Cologne/Weimar/Vienna 2010.

${ }^{29}$ Wiebke Janssen, Halbstarke in der DDR: Verfolgung und Kriminalisierung einer Jugendkultur, Berlin 2010. Cf. Mark Fenemore, Die anderen Leipziger Meuten: Halbstarke und Beatfans in Leipzig. In: Leonard Schmieding/Alfons Kenkmann (Eds.), Kohte, Kanu, Kino und Kassette: Jugend zwischen Wilhelm II. und Wiedervereinigung, Leipzig 2012, pp. 121-140.
} 
new music. Elvis and Little Richard provided the soundtrack to new forms of youthful rebellion „Made in the GDR“.

The way in which the SED responded to these new gangs was to use overt intimidation, violence and humiliation. The act of tuning in to Western radio was arbitrarily condemned as being „hostile to the state“. Particularly in the 1950 s, the regime was prepared to sanction and encourage the use of violence against young people who visibly deviated from party-imposed norms. Thus, youth club leaders were admonished for shying away from ,talking with their fists". Local party officials were quite ready to sanction violence - at least in the form of punches and kicks - in their quest to deal with nonconformist behaviour. ${ }^{30}$ Brute force and intimidation were frequently encouraged as means of dealing with problem youth. The People's Police could therefore feel justly proud of themselves for putting gang members in hospital.

\footnotetext{
Zur endgültigen Beseitigung der Pressley-Bande [sic] hatte folgender Vorfall beigetragen: Als die Bande sich Ende Oktober 1958 wieder auf dem Fussweg breitmachtet, wurde sie von einer Anzahl Bürger derartig verdroschen, dass einige sich in ärztlicher Behandlung begeben mussten... Durch diese "Selbsthilfe" der Bürger wurde gleichzeitig die sogen. 42er Bande aufgelöst. $^{31}$
}

\footnotetext{
${ }^{30}$ Protokoll des Berichtes über die Arbeit im Klubhaus Erich Zeigner am 18.9.1953, 3.2.1954 (StAL IV5/01/483).

${ }^{31}$ BDVP: Bericht über die Presley und 42er Bande, 10.12.1958 (StAL BDVP 24/113, 90).
} 
By ,self-help”, they meant Stasi-orchestrated intimidation and violence. In unconscious emulation of the Nazis, the SED sought to institutionalize this everyday threat of beatings against young people who failed to conform by creating paramilitary ,order groups” (Ordnungsgruppen) with a remit to pressure and intimidate the gangs into submission. ${ }^{32}$

\begin{abstract}
Ziel dieser Ordnungsgruppen ist, an Brennpunkten innerhalb der Jugend zum Einsatz zu kommen mit dem Inhalt, Verbindungen zu diesen negativen Teilen der Jugendlichen herzustellen, Einfluß auf sie zu gewinnen und sie wenn irgend möglich - an die FDJ-Arbeit bzw. gesellschaftliche Tätigkeit heranzuführen. ${ }^{33}$
\end{abstract}

As helpers of the state and security organs of the GDR, the Order Groups had the task of ensuring the maintenance of internal order and security. For many young people, however, the Order Groups were little more than "organisierte FDJ-Banden". ${ }^{34}$ Although a nice idea in theory, it proved difficult in practice to find sufficient numbers of young people who were both ideologically committed and foolhardy enough to be prepared to engage in unarmed combat with the gangs. As one young man put it, „Wir lassen uns doch nicht von den Rowdies zusammenschlagen. Einige andere machen die Erklärung ihrer Bereitschaft von der Zusicherung abhängig, daß sie nicht mit bloßen Händen die Auseinandersetzung mit Rowdies führen müßten und stellen die Frage, ob sie Gummiknüppel oder Pistolen erhalten. “35

\footnotetext{
${ }^{32}$ Michael Walter, Die Freie Deutsche Jugend: ihre Funktionen im politischen System der DDR, Freiburg 1997, pp. 151-159.

${ }^{33}$ Der Kampf gegen Jugendkriminalität und Rowdytum im Bezirk Leipzig, no date, ca. 1960 (StAL, BDVP 24/113, pp. 213-242, here 229).

${ }^{34}$ Einsatz an den erw. Oberschulen, 19.10.1961 (BArch. DR2/6298, 84).

${ }^{35}$ Durchführung des Beschlusses des Sekretariats der Bezirksleitung "Zu einigen Fragen der Jugendarbeit und
} 
Although they could be brought in as a conspicuous and muscular presence at political meetings and on the door at discothèques, out on the street they were in enemy territory. There, their uniforms and kung-fu training were hopelessly unequal to the hit-and-run guerrilla-warfare tactics of the gangs, whose rules of engagement owed little to the Marquis of Queensberry. Nevertheless, the construction of the Berlin Wall in August 1961 allowed the regime to come down hard on nonconformists. It loudly announced that order groups were to be formed throughout the republic. Their re-introduction was part of a raft of repressive measures designed to tackle youth nonconformity, including the introduction of military service for all young men and the erection of special punishment camps for the 're-education' of "work-shy youth". ${ }^{36}$ Overall, it was proposed to create 4,000 new order groups with a total membership of 30,000 "to tackle the persistence of capitalist Unmoral among young people. They were to receive pre-military training for their 'Kampf gegen Rowdys, kriminelle Elemente, Spekulanten... [und] Handlanger des Klassengegners". ${ }^{37}$ One of the first tasks given to the order groups was the implementation of a campaign entitled 'Blitz against NATO senders' designed to "encourage" the population to turn their aerials around and stop receiving radio and television from the West. In a move described as "Nazi" and "medieval" by spectators, the regime tried to use young people as shock troops in its war against Western media infiltration.

dem Auftreten der Rowdygruppen", 13.10.1965 (StAL IVA-5/01/269, p. 226).

${ }^{36}$ Beschluß [des Sekretariats des ZR der FDJ] über die Ordnungsgruppen der FDJ, 22.8.1961 (BArch. SAPMO, DY24/3753-I); Analyse der Entwicklung der Jugendkriminalität im Bezirk Leipzig, 1962 (StAL BDVP 24.1/420, pp. 85-86).

${ }^{37}$ Amt für Jugendfragen Protokoll, 13.9.1961 (BArch. SAPMO DY6/3937; StAL, BDVP 24/113, pp. 97-98). 
The renewed offensive against Western nonculture combined denunciation with intimidation. Coming as it did only a week after the building of the Berlin wall, the drive to clean up the airwaves received mainly lacklustre responses from FDJler with comments like "Wir wollen es doch nicht wie die Nazis machen und an den Tören horchen" and "wir haben in dieser Woche genug für die FDJ gemacht." 38 Parents, too, were less than sympathetic to an attempt to use their children as enforcers of regime policy. One young man remembered his father telling him that if he touched the aerial, then he would have no hesitation in throwing him off the roof. ${ }^{39}$ Nevertheless, some areas saw young pioneers being sent round to pin donkey's ears to the doors of people whose aerials still pointed to the West. ${ }^{40}$

Although, again under Soviet pressure, the campaign was soon called off, interviewees remembered growing up with the knowledge that they could get themselves and their parents into serious trouble if they were found out and denounced for tuning in to Western stations. ${ }^{41}$ The Communists' hostility to Western media was persistently seen in the light of the Nazis' attempts to prevent the population from listening to alternatives to official indoctrination and propaganda. After his arrest for counter-revolutionary opposition, Hans-Peter D., remembered being asked what radio stations he received. After trotting out the usual - Radio

\footnotetext{
${ }^{38}$ Bericht über den Einsatz am 3. und 4. Oktober 1961 in Leipzig (BArch. Berlin, DR2/6956, 27); Ergebnisse im Zusammenhang der Regierungsmaßnahmen, 13.8.61 (StAL, BDVP 24.1/201, p. 63; StAL, FDJ Bezirksleitung Leipzig 82, Box Nr. 79).

${ }^{39}$ Interview with Wolfgang F.

${ }^{40}$ Genossen Kurt Hager, Volksbildung: Information über die politischen Auseinandersetzungen mit Lehrern, Eltern und Schülern gegen den Empfang von Westsendern, 4.10.1961 (BArch. SAPMO DY30/ IV2/905/27, pp. 26-31).

${ }^{41}$ Interview with Dieter L.
} 
Luxembourg, RIAS and AFN - he was asked if there were any more. "Yes", he replied, "the BBC and Radio Moscow." 42

Within institutions for juvenile offenders, a harsh and brutal regime was encouraged.

\begin{abstract}
Am 24.8.61 wurden zwei Strafgefangenen vor ihrem Einschluß in die Station I grundlos mit einigen Fußtritten, Beinstellen und einer Ohrfeige behandelt. Auf anschließender Frage warum dieses geschehen sei, wurde geantwortet, daß Strafg. sich geäußert hätten, die Arreststation wäre für sie nur eine Erholung. ${ }^{43}$
\end{abstract}

Although on this occasion they were reproached by the authorities, mistreatment of young offenders (political or otherwise) by prison guards was routine. In addition to the officially meted-out punishments, there was the everyday harassment and ever-present drill. ${ }^{44}$ Young offenders institutes, like the notorious Jugendwerkhof Torgau, were run in accordance with Prussian traditions of military discipline. Much of the daily routine consisted of compulsory sport (Zwangssport), designed to push inmates to the limits of physical exhaustion, together with punishing cleaning details. ${ }^{45}$ Those arrested by the Stasi remember routinely being deprived of food, being forced to stand with their noses to the wall for hours on end and

\footnotetext{
${ }^{42}$ Interview with Hans-Peter D.

${ }^{43}$ Bericht über den praktischen Einsatz des Offizierlehrganges (SV) vom 24.8.1961 bis 26.8.61 in der STVA Torgau (StAL, BDVP 24/1/956, p. 20).

${ }^{44}$ Brigitte Oleschinski et al, Der Geschlossene Jugendwerkhof Torgau. In: Falk Blask/Gert Geissler (Eds.), Einweisung nach Torgau. Texte und Dokumente zur autoritären Jugendfürsorge in der DDR, Berlin 1997, pp. 93-178, here 121.

${ }^{45}$ Ibid, pp. 121-124.
} 
being subjected to interminable interrogations at all times of the day and night. As they remembered it, their captors "behaved like the Gestapo in films", forcing their victims to squint into bright lights, while they paced up and down malevolently behind them, sometimes coming over to whisper things into their ears, at other times threatening to become physical. Some were beaten; others were not; there was never any reason or logic to it. It was just something they knew they could get away with.

Several of those who had been on the receiving end of Stasi interrogations remember their questioners playing a "good cop, bad cop" game with them. After days of being harangued, misinterpreted and misquoted, disorientated by lack of sleep and the unfamiliarity of their surroundings, they would be approached by a younger officer who would tell them that he believed them. ${ }^{46}$ Although to the guards and prison administration it appeared completely usual and normal, when members of the general public witnessed the punishment meted out to young would-be escapers, they were sickened and openly voiced the opinion that those involved were as bad as the Nazis.

Am Boden liegend erhielt J. vom VP-Angehörigen M. und F. eine Serie von Fußtritten und Fausthieben, bis er, im Gesicht blutend über den Hof bis zu dem auf der Strasse wartenden Gefangenentransportfahrzeug geführt wurde. Im Hof befanden sich noch 4 weitere VP-Angehörige sodass die Gefahr einer erneuten Flucht nicht bestand.

Am Transportfahrzeug wurde J. vom VP-Hwm. M. mit einem Fußtritt ins Wageninnere befördert, sodass er dort stolperte.

\footnotetext{
${ }^{46}$ Interview with Dieter L.
} 
Im Bereich des Grundstückes Elbstrasse 9 hatte sich unterdessen eine etwa 30 köpfige Menschensammlung gebildet, welche durch Zwischenrufe, wie "SS - und Gestapomethoden, wir sind doch nicht mehr bei den Nazis" ihren Unwillen zum Ausdruck brachten.

Im Hof des Jugendhauses wurde der Strafgefangene, nachdem er das Transportfahrzeug verlassen hatte sofort von Ltn. d. VP S. und dem Lehrmeister H. ergriffen und mit Faustschlägen und Fußtritten bis zur Gittertür geschlagen. Während dieser Schläge und Tritte war J. mehrfach zu Boden gestürzt und wurde auch am Boden liegend getreten und mit Fäusten bearbeitet... Am Gitter zum Verwahrhaus hatte sich eine etwa $30 \mathrm{~cm}$ große Blutflache gebildet... Unter den Zuschauern befanden sich neben mehreren VP-Angehörigen auch einige Lehrmeister und Erzieher. ${ }^{47}$

Nevertheless, in spite of the displeasure that such brutal methods aroused among the population, the regime repeatedly embraced draconian, "common sense", knee-jerk solutions to the problem of youth nonconformity, which in their language and methodology closely resembled tactics previously used (to ill effect) by the National Socialists.

Within local communities, the main responsibility for dealing with youth nonconformity fell on the "community policemen" (Abschnittsbevollmächtigte or ABVs). ${ }^{48}$ The ABVs were

\footnotetext{
${ }^{47}$ Sachstandsbericht über die Körperverletzung durch VP-Angehörige des Jugendhauses Torgau, 12.7.1963 (StAL BDVP 24/1/956, pp. 254-257).

${ }^{48}$ Richard Bessel, Grenzen des Polizeistaates. Polizei und Gesellschaft in der SBZ und frühen DDR, 1945-1953.
} 
tasked not only with providing a visible policing presence on the street, but in building up information about local gangs, harassing them and moving their members along for minor breaches of peace and order. ${ }^{49}$

Zur Lückenlosen Erfassung aller Personen und Personengruppen, die als Gammler in Erscheinung treten oder mit solchen in Verbindung stehen, wird vorgesehen...

1. Alle operativen Kräfte haben im Rahmen ihrer Dienstausübung bei dem oben bezeichneten Personenkreis Ausweiskontrollen durchzuführen.

2. Die ABV haben eine Aufstellung über die oben bezeichneten Personen und Personengruppen mit Name, Vorname, Geburtstag, Wohnanschrift und Anschrift der Arbeitsstelle zu fertigen.

3. Kraftfahrzeuge, die von oben bezeichneten Personen oder Personengruppen benutzt werden und durch ihre äußere Beschaffenheit (Farbe, Aussehen, Einrichtung) im Straßenverkehr negativ auffallen, sind anzuhalten und die Feststellung der Personalien der Führer solcher Fahrzeuge wie unter 1. angewiesen.

In the eyes of many people, the ABVs were not all that dissimilar from the "block wardens" (or Blockwärter) employed by the Nazis. ${ }^{50}$ As the "eyes and ears" of the state, they relied In: Richard Bessel/Ralph Jessen (Eds.), Die Grenzen der Diktatur. Staat und Gesellschaft in der DDR, Göttingen 1996, pp. 224-252, here 240-243.

${ }^{49}$ Vorschläge zur wirksamen Verdrängung verbrecherischer und rowdyhafter Handlungen durch Gammler, 20.10.1965 (Landesarchiv Berlin, STA Rep. 303/26.1/490 Jugendkriminalität 1964-1966, pp. 159-160).

${ }^{50}$ Hans-Joachim Ehrig, Kontaktbereichsbeamte: wichtiger Mosaikstein eines Systems umfassender polizeilicher 
heavily on local gossip and hearsay, officially characterised as "reputation (Leumund)", for identifying potential deviants and trouble-makers.

The language and notions used to label and stereotype young people who did not fit into the regime's blueprint for youth often bore a striking resemblance to the language used in the Third Reich to describe young people who failed to conform to the norms of the "national community". Like the Nazis before them, the Communists were very worried about "workshy" tendencies and "parasitism" among youth. The tendency of young, unskilled workers to change jobs frequently in order to increase their wages or independence and to avoid employers who did not treat them well, merged for the SED with the skiving of young workers who were addicted to alcohol or who had problems ordering and planning their lives. ${ }^{51}$ While at certain periods, the Communist authorities chose to see the latter as people suffering from problems, who needed the regime's help and supervision to overcome them and to live healthy and productive lives, at other times it attacked what it saw as the deliberate refusal of such "feckless" young people to contribute fully to the project of the construction of socialism. During periods when the pendulum had swung back to repression and coercion, "work-shy elements" among youth were singled out for special treatment and "re-education" in work camps. There, in language highly reminiscent of the ethic of National Socialist Concentration Camps, they were to learn the value of hard labour.

Public vilification of young people often used the language of "filth" and "infection", depicting young people as disease-ridden parasites, in one instance with hair eaten away by

Kontrolle; ein Vergleich mit dem Blockwart der Nazis und dem Abschnittsbevollmächtigten der DDR-Vopo, Berlin 1979 (Initiative gegen das Einheitliche Polizeigesetz, 2nd Edn).

${ }^{51}$ Peukert, Inside Nazi Germany, p. 162. 
rats. ${ }^{52}$ Frequently the negative images created of young people alluded to racial and sexual stereotypes. The black origins of jazz and Rock ' $n$ ' Roll were referred to in comments about young people listening to "ape music (Affenmusik)" and wearing "monkey shirts (Affenhemden)". ${ }^{53}$ Policemen assumed that young men who listened to black music must be a threat to women and viewed them as potential rapists. Any girls who willingly associated with them must be depraved or diseased. One of the young fashion victims blamed for the 1953 uprising, for example, was described as having "doubtful girls (zweifelhafte Mädchen)" on his arm. Only girls with dubious morals would find his boogie-woogie shirts and his BeBop haircut just right. ${ }^{54}$ Only dishonourable and ignoble girls could be attracted to such contemptible young men. Later in the 1950s, female Rock'n Roll fans were said to believe that "die Laufbahn... einer Nutte in Westberlin sei das für sie Geeignete". ${ }^{55}$ The exercising of freedom in dress and choice of company was equated with pollution and dishonour.

Seeing them as worse than prostitutes, on at least one occasion, girls who danced openly with the rocker boys were rounded up and forced to undergo tests for venereal disease. „In den letzten Tagen mußten aus den Parkanlagen, vorwiegend vom Musikplatz, 11 weibliche Jugendliche zugeführt werden, von denen 5 Mädchen infolge einer Geschlechtskrankheit in ärztliche und stationäre Behandlung gebracht werden mußten. ${ }^{\text {"56 }}$ Although SED denunciation

\footnotetext{
${ }^{52}$ Vogelscheuchen in der Peterstraße. In: Leipziger Volkszeitung, 23.7.58.

${ }^{53}$ Protokoll des Berichtes über die Arbeit im Klubhaus Erich Zeigner am 18.9.1953, 3.2.1954 (StAL IV5/01/483).

${ }^{54}$ Diebe, Straßenräuber, Brandstifter - das sind die "Ritter der abendländischen Kultur“. In: Neues Deutschland, 1.7.1953.

${ }^{55}$ Vogelscheuchen in der Peterstraße. In: Leipziger Volkszeitung, 23.7.58.

${ }^{56}$ Stellungnahme zur Bekämpfung des Rowdytums - Brennpunkt Klara-Zetkin-Park, 24.8.1960 (StAL BDVP 24/113, pp. 167-175, here 172).
} 
of Rock'n Roll as "infectious" and "like a disease" reflects earlier National Socialist condemnation of Swing music, it is important to note that even in liberal democracies like Britain in the 1950s and 1960s, it was common to describe youth subculture as being "like a disease". "People are somehow 'infected' by delinquency, which 'spreads' from person to person, so one has to 'cure' the 'disease'." 57

\section{MORAL PANICS}

Although the methods of conflict and coercion employed by the regime had both Stalinist and Nazi overtones, they also contained a novel component, that of the "moral panic". Stanley Cohen coined the term "moral panic" to describe media-induced frenzies in which stereotypes and myths were created by the press and projected onto conspicuous groups of young nonconformists, so that they became identifiable as modern-day "folk devils". "Societies appear to be subject, every now and then, to periods of moral panic. A condition, episode, person or group of persons emerges to become defined as a threat to societal values and interests; its nature is presented in stylized and stereotypical fashion by the mass media." 58

Examining the clashes which occurred between the mods and the rockers in English resort towns during the early 1960s (immortalized in The Who's 1979 film, Quadrophenia), Cohen analyzed the role of tabloid-style exposés in exaggerating behaviour, attributing causes and motives and generally heightening tension. Media reports on youth subculture did a great deal

\footnotetext{
${ }^{57}$ Cohen, Folk Devils, p. 62.

${ }^{58}$ Ibid., p. 9; cf. Erich Goode/Nachman Ben-Yehuda, Moral Panics. The social construction of deviance, Oxford 1994.
} 
to popularize a particular subcultural style, to give it associations and meanings as well as creating expectations about the sorts of activities and behaviour which went with the particular style of dress or haircut. "Through symbolization, plus other types of exaggeration and distortion, images are made much sharper than reality." ${ }^{, 59}$

\begin{abstract}
An initial act of deviance, or normative diversity (for example, in dress) is defined as being worthy of attention and is responded to punitively. The deviant or group of deviants is segregated or isolated and this operates to alienate them from conventional society. They perceive themselves as more deviant, group themselves with others in a similar position, and this leads to more deviance. ${ }^{60}$
\end{abstract}

In the process, media coverage created a confrontation which would not otherwise have existed. In addition, Cohen pointed to the predictive power of the press in creating an expectation on the part of both young people and the authorities that, under a given set of circumstances, a confrontation would occur. "There is the implicit assumption, present in virtually every report, that what had happened was inevitably going to happen again." ${ }^{61}$ As was frequently the case in the GDR, so too in the West, the media also persistently had the urge to uncover shadowy forms of organization lurking behind apparently mindless acts of hooliganism. The "indiscriminate persecution, local overreaction and media stereotyping

\footnotetext{
${ }^{59}$ Cohen, Folk Devils, p. 43.

${ }^{60}$ Ibid., p. 18.

${ }^{61}$ Ibid., p. 38.
} 
suggested a 'cabalism', that is, the solidifying of amorphous groups of teenagers into some sort of conspiratorial collectivity, which had no concrete existence." 62

In addition to presenting young people as "agents" and "saboteurs", deviants and people who transgressed community norms, the East German press also emphasized their alienness and otherness in a similar fashion and language to Western tabloids. Neues Deutschland criticized their ,verwahrloste, lange, zottlige, dreckige Mähnen, zerlumpte Twist-Hosen. Sie stinken zehn Meter gegen den Wind. Denn Waschen haben sie 'freiheitlich' aus ihrem Sprachschatz gestrichen". ${ }^{63}$ As far as young Beat-fans were concerned, the campaign against their music, clothing and haircuts represented a deliberate misinterpretation of youth culture and an attempt to demonize their behaviour. „Diesen Artikel lehne ich ab. Er mutet an wie ein Sensationsbericht von Springers Achtgroschenjungen aus der 'Bild'-Zeitung'“, one reader complained, „Es wurden in unglaublicher Form Tatsachen mit Lügen und Verleumdungen vermischt und damit dem Leser ein verzerrtes und unwahres Bild vorgetäuscht. “64

Reports on youth subculture in East Germany used similar techniques of exaggeration, laying stereotype on stereotype until they had created a phenomenon, which bore little resemblance to the original. The extraordinary young people then served as folk devils, or "visible reminders of what we should not be". Once type-cast as deviants and rule-breakers, they became "disembodied objects, Rorshach blots (sic) onto which reactions are

\footnotetext{
${ }^{62}$ Mike Brake, Comparative youth culture: the sociology of youth cultures and youth subcultures in America, Britain and Canada, London 1985, p. 64; Cohen, Folks Devils, p. 63.

${ }^{63}$ Die Amateur Gammler. In: Neues Deutschland, 17.10.65.

${ }^{64}$ Analyse der Leserzuschriften zu Problemen der Jugend, Leipzig 26.11.1965 (StAL, SED IV A-2/16/464, p. 163).
} 
projected". ${ }^{65}$ As in the West, East German reports on youth subculture had a counterproductive, self-realizing effect in warning of clashes and confrontations, which then duly appeared. This was most notable during the run-up to the Beat demonstration in Leipzig in October 1965, when young Beat fans reacted angrily to what had been printed about them in the press and to official attempts to ban their music. Far from putting young people off a particular style, hostile press coverage only served to make it more popular. Negative media attention became a self-fulfilling prophecy. When members of a street gang in a village twenty miles away from Leipzig read about the Beat demonstration there, they were so impressed by the photographs of tattoos (supposed to put young people definitively off Beat) that they copied the designs and slogans for their own Do-it-yourself tattoos.

Nach den Zusammenrottungen von Beatanhängern im Oktober 1965 sah ich ein Foto in der 'Leipziger Volkszeitung' über eine Tätowierung, die sich am Körper einer derartigen Person befand. Den Artikel dazu habe ich allerdings nicht gelesen. Mir gefiel die Tätowierung, woraus die Worte 'USA', 'Treue' und 'Geld' hervorgingen, die meiner Einstellung auf Grund des Einflusses der Westsender entsprach, und um damit bei anderen Jugendlichen Eindruck zu Machen, brachte ich die gleiche Tätowierung mittels zweier Nadeln und Ausziehtusche auf dem rechten Unterarm selbst an. ${ }^{66}$

\footnotetext{
${ }^{65}$ Cohen, Folk Devils, p. 25.

${ }^{66}$ Bundesbeauftragte für die Unterlagen des Staatssicherheitsdienstes der ehemaligen DDR (BStU), Ast. Lpz., AU 762/67, Band II, 38.
} 
Cohen also described the process of "spurious attribution" by which "one incident, type of behaviour, or type of person" is associated "to a whole spectrum of problems and aberrations". ${ }^{67}$ Through the creation of moral panics, the media conveys the message that the behaviour is related to a contemporary social malaise. As in the West, so too in the East, a number of different "spurious attributions" competed to explain the phenomenon of youth subculture. As well as denouncing Beat fans as dirty and dishevelled, promiscuous and workshy, the SED also argued that they were abusing the freedoms and opportunities made available to them by a generous Party. In spite of the regime's emphasis on the equality of men and women, working and particularly single mothers became favourite targets on whom to pin the blame for youth nonconformity. ${ }^{68}$

The major difference between the creation of moral panics in East and West, however, was the fact that, in the East, press and police were parts of the same structure of one-party rule. In the West, newspapers engaged in labelling and stereotyping to increase their sales figures while magistrates gave "sound-bites" about "long-haired, mentally unstable, petty little hoodlums... who can only find courage like rats, in hunting in packs" to increase their standing in the local community. ${ }^{69}$ Western newspapers justified their prurient interest by helping to obtain a tougher response for youth subcultural offenders. In East Germany, both press coverage and sentencing were very much subordinate to the dictates of the Party. The newspapers acted as cheerleaders while the police persecuted and the judiciary passed sentence on young people because all three were closely controlled by the SED. In a country where the law was bent to the political will, the judiciary lacked independence and

\footnotetext{
${ }^{67}$ Cohen, Folk Devils, pp. 54-55.

${ }^{68}$ Bekämpfung der Kinder- und Jugendkriminalität 1962-1964 (StAL, RdB Bildung, Kultur \& Sport 5449).

${ }^{69}$ Cohen, Folk Devils, p. 88.
} 
objectivity, the press was pliant and muzzled, and there was no real local or national democracy. In these circumstances, it was much easier for young people to be judged solely on their appearance and designated guilty of heinous crimes simply on the basis of spurious attributions and associations. $^{70}$

In their attacks on youth subculture, the East German authorities drew on a range of elements drawn from Stalinism, National Socialist notions of national community, together with prevailing, contemporary, international trends for castigating and misrepresenting youth as a threat to themselves and to society. But there was always a special added touch which differentiated East German repressiveness from other types of repression - that peculiar blend of pathos, cynicism and naivety that could make it seem like a good idea to call the wall imprisoning the population an "antifascist protection barrier" or to hold military manoeuvres on the site of the Buchenwald concentration camp. In October 1965, representatives of the armies of the GDR, Poland, Czechoslovakia and the Soviet Union met to pay their respects to the brave antifascists and the victims of Nazism. But they were also determined to demonstrate their readiness to use force against the enemies of socialism. ${ }^{71}$ In a speech marking the contribution of the People's Police to the manoeuvres, Comrade Major General Dahl, the Leipzig Chief of Police, spoke of how they had found work for the criminal and work-shy elements who had protested against the ban on Beat:

\footnotetext{
${ }^{70}$ Dieter Plath, Über Kriminalität und innere Sicherheit. In: Günther Agde (Ed.), Kahlschlag. Das 11. Plenum des ZK der SED, Berlin 1991, pp. 32-38, p. 36.

${ }^{71}$ Der Schwur von Buchenwald. Gedanken zum feierlichen Meeting der am Manöver "Oktobersturm” teilnehmenden Truppen und der Weimarer Bevölkerung. In: Neues Deutschland, 20.10.1965.
} 
Wir haben in den letzten Tagen Jugendliche, die von der Vorbereitung der Jugendweihe zurückgekommen sind, die überfallen worden sind, ausgeraubt, belästigt und junge Mädchen wirklich unsittlich angefaßt worden sind...

Die Gammler hatten bei sich: Pistolen, feststehende Messer, Schlagringe, usw.

Wir hatten sie untersuchen lassen und es hat sich gezeigt, daß eben viele Gammler - und das kann niemals unsere Jugend sein und daß kann niemals ein Idol der fleißigen Jugend sein - derart schmutzig und dreckig waren, daß wir sie erst waschen und ihnen die Haare verschnitten werden mußten. Wir mußten erst einmal die Ärzte holen, weil wir festgestellt hatten, daß verschieden geschlechtskrank waren.

Mit diesen Elementen Schluß zu machen, ist auch die Aufgabe der Volkspolizei...

Sie glaubten, daß sie die Clubhäuser oder die Tanzgaststätten unserer jungen Menschen dazu benutzen können, um dort auf ihre Weise das Mobiliar zu zerschlagen und einiges mehr. Wir haben dafür gesorgt, daß wir sehr schnell Ordnung und Sauberkeit in unserer Stadt haben und wir werden das auch gemeinsam mit der Bevölkerung unserer Stadt durchsetzen zum Ruhme unserer Stadt und damit man davon sprechen kann: Jawohl, in Leipzig wohnt es sich sehr ordentlich, gut und ruhig! ${ }^{72}$

\footnotetext{
${ }^{72}$ Stenografisches Protokoll: Jugendaussprache "Die Jugend und der Oktobersturm" am Mittwoch, dem 3.11.1965 in der Kongreßhalle Leipzig (StAL, IVA-5/01/269, pp. 146-183).
} 
All the participants in the Beat demonstration were smeared with sexual contagion as well as ideological infection. The notion of respectability was used to persecute an embarrassing and troublesome minority.

\title{
CONCLUSION
}

The SED was aware that many of its problems in controlling young people stemmed from the conditions they had grown up in in the aftermath of the war. As Erich Honecker put it:

\author{
Wir haben einige Jugendlichen, die in zerrütteten Familien der \\ Nachkriegszeit aufwuchsen, die den Abschluß der 8. Klasse nicht \\ erreichten, die keine ordentliche Lehre aufnehmen konnten, die von der \\ sozialistischen Jugendorganisation kaum betreut wurden, die kaum Erfolge \\ in ihrer Arbeit hatten, die sogar der Arbeit fernbleiben und schließlich auf \\ die schiefe Bahn gerieten. Solche junge Menschen sind der \\ imperialistischen Sexual- und Kriminalpropaganda gegenüber besonders \\ anfällig. ${ }^{73}$
}

Nevertheless, steeped as they were in antifascist myth, in which only the Communists had bravely stood up to National Socialism, SED leaders were able to see youth subcultural nonconformists as "fascist spawn". ${ }^{74}$ Not only were they unsympathetic to the plight of many

\footnotetext{
${ }^{73}$ Der Vater verließ den Saal. Beobachtungen und Notizen bei einem Jugendprozeß. In: Neues Deutschland, 19.12.1965.

${ }^{74}$ Vorwärts, 22.6.1953, p. 3.
} 
of these supposed delinquents, but they were prepared to imprison them and eradicate their culture - "Die Keime der Bösen auszurotten, welcher Wind auch immer sie uns bringe" with a clear conscience. ${ }^{75}$ Young people had once been presented as the great hope for the future because they were the one section of German society (aside from the Party leadership) untainted by National Socialism. However, in the Winter of 1965, young people's privileged, untainted position in relation to the past was revoked and taken away from them. They were no longer seen as safer, but as more dangerous because they lacked direct exposure to Nazism. ${ }^{76}$

For historians, the abuse of young Christians demonstrates the way in which any minority, however morally upstanding, could be targeted for persecution by a dangerous and illiberal regime. The examples provided by the subcultures suggest a more morally ambiguous situation. Interest in music, fashionable clothing and dancing often overlapped with aggressive defence of territory and engagement in delinquent activities. Members of the subcultures were prone to drinking and violence; they could become involved in minor criminal activity for kicks. Their basic outlook was little different from British subcultural groups like the mods and the rockers, singled out as "folk devils" during a mass-mediated moral panic. The authorities in East and West exhibited similar knee-jerk authoritarian responses, but although British magistrates manifested overt hostility to delinquents and sought to impose deterrent sentences, they remained constrained by a system operating according to the rule of law. As a result, in spite of headline-grabbing hyperbole, the violence of their response remained largely symbolic. The East German authorities, although not on the same moral plane as the genocidal Nazi regime, were less constrained by legal niceties

\footnotetext{
${ }^{75}$ Der Vater verließ den Saal.

${ }^{76}$ Ibid.
} 
than their counterparts in the West. They could deploy the "short sharp shocks" envied by the readers of western tabloids while vilifying nonconformists using conservative language. In many ways, the attack on the Beat subculture, whose members dared to challenge the official monopoly on cultural expression, was an exercise in scapegoating. The regime's economic reforms were failing and writers and other artists were growing restive with the restrictions on their work. By condemning the Beat fans, the regime could abruptly end its reform period, turn back to repression and engineer a generational conflict - in the process fostering the population's hostility to the Beatles fans, whose long hair now obscured their vision into the future. ${ }^{77}$ Youth was just a pawn in the wider game of the cold war.

\footnotetext{
77 Agde (Ed.), Kahlschlag.
} 